\title{
TURIA RZYMSKIM SYMBOLEM MIŁOŚCI I WIERNOŚCI MAŁŻEŃSKIEJ
}

Turia - to bohaterka pewnej "laudat1o funebris", która dziegi dośc obszernie zachoranym fragmentom zawiera bogaty materiaz do poznania zarówno zycia politycznego 1 społecznego, jak równiez do histor11 pewnego małzenstwa rzymskiego oraz miłośc1 1 poświęcenia zony wobec męza. Zasługuje to na szczególną uwage, poniewaz inskrypcja pochodz1 z okresu, w którym dokonywały sie z jednej strony wielk10 przemiany społeczno-gospodarcze, z druglej zaś - upadek moralny społeczeństwa 1 rozkład rodziny rzymskiej, od wiekó pełniqcej tak wazna role społeczna, polityczna 1 religijną. Wymieniona laudatio jest jednak dowodem, jak uogólnienia te moga być krzywdzące.

Nie jest to jedyna tego rodzaju pośmiertna pochwała. "Laudat10 Punebrisn' - to w antycznym świecte rzymskim azczególnte uroczysta Iorma zwiazana z bogatym obrzędem pogrzebowym. Jej tematyka była tak róznorodna, jak rózne sa losy 1 zycie ludz1. Przedstawiano miej przede wazystkim zalety zmarłego w rózych aspektach: comitas, magnitudo an1ai, clement1a, lustitia, benignitas, p1des, fortitudo in periculis, sapientia ... Forma ta rozwineła sie dość wcześnie, bo juz w v. prz. Chr. N1e ma jednak pewnó́ci, kiedy miata miejace plerwsza pochwaza kobiety. Cicero wspomina wystapienie z mowa pochwalna K.Lutacjusza Katulusa, który w ten sposób zło-

I Jest to eragment pracy magistorskioj pt. "Laudatio Turiae. Totęp, tekst, przekład, komentarz, Lublin 1980", pisanej pod kierunkiem prof.dr L.Małunow1czówny na Sekoj1 Filologil Klasycznej KUL /mps BKUL/.

1 Por. F.Vollmer, Laudatio Punebris, RE XII 992-994; tenze, Laudat1onum funebrium Homanorum historia et reliquiarum edit1o, "Jahrbacher far klassische Philologie", Leipzig 1892, Supp1. 18; J.Marquardt, Das Privatleben der Romer, Leipzig 1856, 417-421; S.Zabłock1, Antyczno epicedium 1 elogia załobno, Wrociav 1965. 
zyl hold smojej matoe Pop $1111^{2}$. Z czasów późniejszych znamy wiele laudacj 1 dotyczących bobiet z rodziny Cezara 1 z rodzin nobllóm. Wéró tych ostatnich znane sa m.1n.: "Laudatio Murdisen" "Laudat10 Matidiae ${ }^{4}$ oraz interesujace nas "Laudatin Turiae"5. Ta waśnie inskrjpcja, myryta na maraurowych tablicach $w$ dwu kolumnach, dotarza do nas slodmlu fragmentach z licznymi lakunami, któro stanowia czmartą czéśc tekstu. Lowa koluma zachómała sie tylko odplasch, vykonanych XVI 1 XVII wieku. Datowanio inskrypcj1 nio sprawia wekszyor trudnó́ci. ponlewaz zawiora mielo szczegózóm historycznych. Fynika z nich, to epttarlum to mogto byd wyryte miedzy 8 a 2 r. prz. Chr. 1 atsnow odzwierciedlenie 1086 pary mazzerikiej 1 jef milośl na t10 wydarzof 1 procesón historycznych zachodzacych $\approx$ I weku. Początkowo lersze nap1su wpowadzaja nas w okres wojny domowej o vadze miedzy Pompejuszom 1 Cezarem, po zamordowaniu któro-

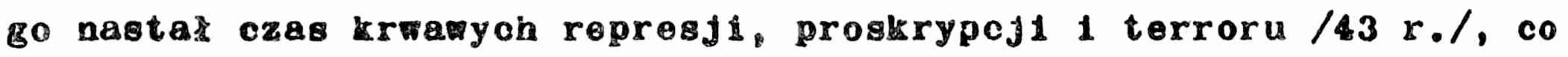
we bozpórednt wazok z 10som mezo Tur11. Walk1 wewnęrzno, wajemo na nieurnost oraz zyole ponad stan zamazy ry róniez w decydujacy sposéb na pogzeblente sie kryzysu rzymaklej rodziny. Coraz bardziej zanike joj patriarchalny charaktor. Koblota jest juz nio tylko panif domu 1 oglekunka ogatgka domowego, ale blerze rowniez udziat wyclu polityczngm, jak to wciséniej czyalia chocby Kornelia, matka Grakchó, czy Sempronta, zona D.Brutuea, Mozna przy tym wyliczyć wie1e przykzadów tz. koblet samodzlelnych, któro nio tylko zarzadzały wasnym majątkiem 1 decydowazy o swolm loste, ale równiez porzucaIy swolch męóm dla innych. W tym kontokście zrozumiala jest niochę do mazerístwa. Byll jednat 1 tacy, których zycie rótenifo sie - sposub zasadntczy od "typowych" przykiadón tego okrosu. Znana

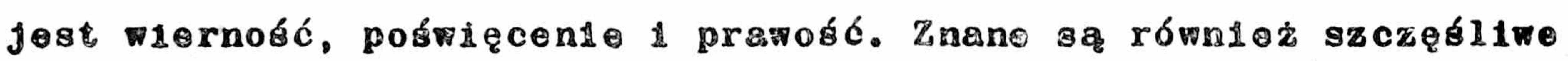
mazcońtra, jak np. Brutusa z Porcja, czy Sulpicj1, ktora prze-

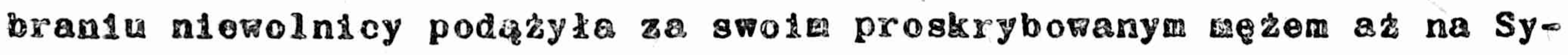
oyl1, czy Mreazc1 bohatork1 naszej fnskrypcjl. Jakio byio jej zy-

2 C1coro, De oratore II 11, tium, E.Fykaczewsk/ Dziola na, t.6. Poznar 1873/87: "Przypominam ooblo, jak mi sie spodoba-

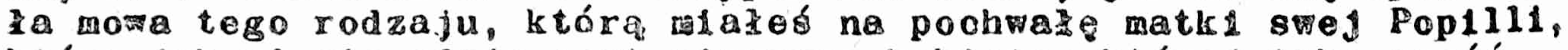

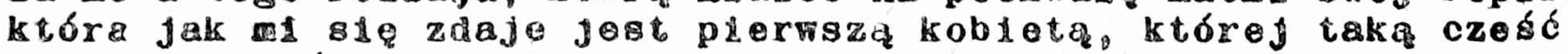

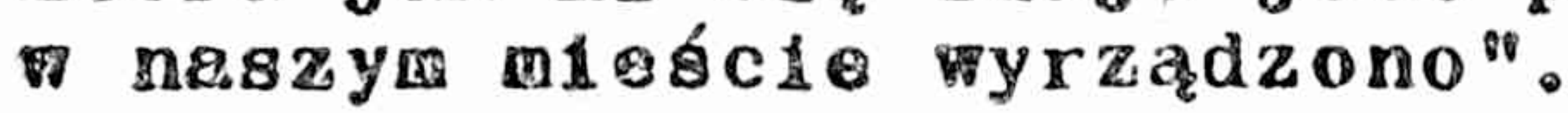

3 CIL VII 10230.

4 CIL XIV 3579 。 
cle 1 czym zasłuzyła soble na tak połnaz wdzlęcznośi pochwałę? Przyjrzyjmy sie jej losom.

W okresie wojny domowej, gdy Cezar doszedł do wadzy, rodzice Turil poniesli śmieré. Turia, wraz ze swą siostrą, oddała sprawę do sadu 1 po wielu przecinnosciach sprawcy mordu zostali ujeci. Wrótce potem dla więsszego bezpieczeństwa przeniosła sie do przyszłej té́ciowej, której dom obroniła przed napadem bandy Milona 48 roku. Wówczas, a moze kilka lat póńnej, wyszka za mąz. Młodz1 małzonkowie niezbyt dzugo mogli sie cieszyé szczę́ciem, gdyz maz został wploany na liste proskrybowanych 1 musiał uciokac z Rzymu. Wtedy Turie udzielila mu pomocy, o której ścigany mąt tak będzle rspominat:

"Udzielizaś mi czasie ucleczki najszerzej pojetej pomocy, zrozumiazaś moje potrzeby, kiedy to przekazalas mi cale zloto 1 perty zdariszy je wręcz ze swego ciała. Zaraz potem podstepnie oszukawszy otraze/molch/przeciwników, wystazas do mnlo szużbę, plentazdze 1 pozymiente"6.

Równiez podczas deobecności męa Turia nle pozostawala blerna, ale bragara u wpymowych ośbb o darowante zycia 1 mozliwość powrotu dla wygnanego węz, co jej się wrótce udało osiagnác:

5 CIL VI 1527 /tekst oryglnalny z lewej 1 prawej kolumny, uszkodzony $8 \mathrm{~s} .332-333$, zrekonstruowany $\mathrm{s} s .334-335 /$; por. równiez CIL VI 316701 37053. Późnłejsze krytyczne wydanta tokgtu por. M.Durry, Eloge Punébre d'une matrone romalne /Eloge dit de Turia/. Paris 1950; A.E.Gordon, A new fragment of the "Laudat10 Tur1ae", "American journal of archeology" 54/1950/223-231; E. Wistrand, The so-called "Laudat1o Tur1ae", Lund 1976; polsk1 przek 1 ophacowante J.Korpanty, Rzymska pochwaka 1dealneJ zony, "Meander" 35/1980/156-164; por. W.0.Gorensztain, Chwalebnaja recz na pocheronach rimskoj matrony "Laudat1o Turiae", "Vestnis Drevnej Istor1" 23/1970/ nr 4, 215-223; J.Sararewicz, Uwag1 o jezyku tzw. "Laudat1o Turiae", "Meander" 34/1979/71-81.

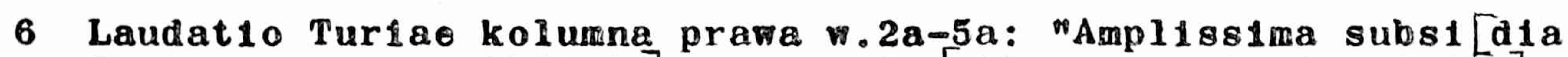
fugao moa praestitist1] ornamentis [vitam meam instruxisti] cum omne aurum margaritaque corpori [tuo detracta trad] idist 1 mihl et subinde femilis numis, fructibus. [callide deceptis ad] versariorum custodibus apsentiam moam iocupletesti". 


\begin{abstract}
"Słusznie Cezar nie chciał $/$ swolm edykcie wspomniec nawet słowem, ze zostałem przez niego przywrócony ojczý́nie, albowiem gdybý́ ty nie uczyniła tego /wszystkiego/, na co on mial zwróc1ć uwage, nadaremnte oblecywalby swoje poparcie, strzegac mojego bezpieczeństwa. Tak więc nie mniej trojemu oddantu niź Cezarond to zawdzi ęczamn?
\end{abstract}

Nie wszyscy Jednak uznali okazanz przez Oktawiana laske wygnanemu, bo kiedy Turia udała sle podczas nieobecności Augusta kzyme do jego zastępcy Marka Lepidusa sprawio powrotu 1 przyørócenia męzowi utraconego urzędu, została potraktowana bardzo surowo:

"... Upadzszy na ziemie do stóp jego, nie tylko nie zostałaś podniesiona, lecz byłaś clagnieta 1 wleczona jak niewolntca, doznając obrazeń ciała. Gdy zaś przypomniałaś mu bardzo odwaznie o zarządzentu Cezara z zyczenlem mojego ułaskawienia, usłyszałaś jedynie obelzyme słowa 1 otrzymałaś okrutne rany, które pokazywałaś, aby był znany sprawca molch nieszczęść. Wkrótce ta sprawa mu zaszkodziłan8.

Oto jeden rozdzlat zycia Turil 1 jej meza odnotowany w instrypcj1. Z nastaniem spokojnych czasów, do szczęśc1a brakowało im tylko potomstwa. Mimo poddania sie wielu zabiegom, które, jak mozna przypuszczać, miały przywrócić płodność kobiecie, sytuacja się nio giolon11a. Turia tracac ostatecznie nadzieje 1 bolejac z powodu bezdzietnośc1 zaproponowała męzomi rozwód, aby przynajmniej on mógł mieć tak upragnione dzieci nawet z inna kobietą. Owszem, posuma sie jeszcze dalej, bo planuje przekazanie majatku /a byto to prawnie mozliwe przy mazzeństwach "sine manu"/ męzowi 1 jego drugiej zonie 1 uznanie dzlecl z tego małzeństwa za swoje. Zwycieza tu jednak pelni

7 Tamze, [verbum] me patriae redditum a se, na]m nisi parasses quod servar [et cavens saluti meae] Inaniter opes suas poll1ce[ret] ur. Ita non minus pietati tu[ae quam Cesari] me debeo".

8 Tamze, w.12-18:"... et 1 [ud] 1cio apsentis Caesaris August1, quom per te] de restitutione mea M.L. [epi] dus conlega praesens intorp[ellaretur et ad elus] pedes prostata hum1, n[on] modo non adlevata sed trac [ta ot servilem in] modum rapsata ilvori [bus o] orporis repleta firmissimo [animo oum admone] res odict 1 Caesaris cum $g[r]$ atulatione restitutionis me [ae auditisque verbis et 1 am contumeliosis et cr [ud] elibus exceptis volneribus pa [1am ea praeferres] uc auctor meorum peric [ul] orum notesceret. Quoi noc [uit mox ea $\left.\operatorname{res}^{n}\right]$. 
miłość 1 wierność małzeńska:

"Muszq wyznać, ze do tego stopnia to mnie oburzyło, ze omal nie oszalałem. Tak bardzo przeraziłem sie twoich zamierzeń, że z trudem doszedłem do siebie. Mam mówić o naszym rozwodzie, jeszcze przed głosem przeznaczenia i wyobrazać sobie dlaczego ty żywa masz przestać byé dla mnie zoną, skoro pozostałaś najwierniejszą, gdy ja byłem prawie pozbawiony zycia"

Małżeństwo zostało uratowane, choć nie na długo, bo sama śmierć rozłączyła tych dwoje ludzi, walczących przez 41 lat o swój wspólny 108.

Autor nie ograinicza sie w swojej laudatio tylko do przedstawienia czynów niecodzieunych 1 nadzwyczajnych, lecz mówi tahże o swojej żonie, jaka była na co dzień, w zwykłym szarym życiu, między wielkimi "wypadkami" histori1. Obok takich cech charakteru jak: odwaga, uczciwośc, oddante, troska o innych, poczucie obowiazku wobec rodziny, szacunek do rodziców - mazz wymienia zalety domowe - domestica bona jak: wstydliwość, oddante, grzeczność, przystępnośc, przędzenie wełny, pobozność bez zabobonów, skromny ubiór czy wreszcie spokojny tryb życia ${ }^{10}$.

Trzeba tu na marginesie zaznaczyć, ze tego rodzaju zestaw1enie 1 nagromadzenie cech $\nabla$ jednym miejscu przypomina doś wiernie konwencjonalny topos stosowany przez starozytnych wowach pochwalnych, czego przykładem może być choćby "Laudatio Murdiae":

"EO maiorem laudem omnium carissima mihi mater meruit, quod modestia, probitate, pudicitia, obsequio, lanificio, diligentia, fide par similisque cetereis probeis feminis fuit"il.

9 Tamże, w.40-43: "Fatear necessest adeo me exa $[r s i]$ sse, ut excesserim mente, adeo [exhorruisse cona] tus tuos, ut vix redderer [mi]hi. Agitari divertia inter nos [posse ante quam $p$ ] ato dicta lex esset, poss [ e te a]liquid concipere mente, qua [re viva desineres] esse mini uxor, cum paene [e] xule me vita fidissuma perman [sisses 17 .

10 Por. tamże, w.30 i nst.

11 Laudatio Murdiae 27-29, CIL VI 10230. 
Zalety ukazane "Laudatio Turiae" nie umniejszyły przeciez niczym jej zyciowej zaradności, umiejętności msṕxzycia, zdolności organtzacjl domu, dbalosel o majątek itp. Potrafiza wiec ona swe niezatwe zycle przezyé zachowujac miłoś do miza zarónno chwllach wlelk1ch nlebezpieczeńst, Jak 1 zwykłych codziennych spraw, co potwierdzaja słowa bolejącego męza:

\section{"... uginam sle od nieszczę́cia ... Naturalny ból odbiera sizy spokojowi. Pograzam sie smutku 1 dławie sie nieszczésciem 1 trmoga, nie mogę odnaleź́ sain siebien12.}

KIm była bohaterka tej lnskrypej1? Wiele sxczegół 6 wawartych 7 napisie wskazuje na Kwintusa Lukrecjusza Fosp1llona 1 jego zone Purie, wspomnianych takze przoz Faleriusza Maksyma 13 Appiana ${ }^{14}$. Przeciw tak1 ej Interpretacji wystepuje Marcel Durry twierdząc, ze jeśliby laudatorem był Lukrecjusz Tespilion, doukrotny konsul 1 calowiok o pewnym znaczenlu państwio, to ujamnizoby sie to w inskrypoji ${ }^{15}$. Nalezy jednak zauwazyc, ze autor naplsu przedstawia pelne doniosłych czynow 1 zasług zycio zony, a o sobie mpomina tylko wtedy, gdy chce w sposób szczególny ukazać dobrodziejstwo ukochanej kobiaty: "multa de hac omittam, ne tus propria mecum communicemn"16. Identypikacja bohaterow inskrypej1 nie została wiec calkowicie ustalona. By c moze prawdziwe imie tej kobiety nadal pozostanie nieznane, stając sie symbolem 1 lelklego uczucla, któremu nie sprzyją anl ozas, anl ludzle.

\section{Anna Kalabun - Lublin}

\section{DE TURIA ROMANI AMORIS CONIUGALIS EREMPLO}

\section{/Argumentum/}

Hac in brevi dissortincula tractatur do amoro lidelitatoque conlugal1, quae in laudatione punobrall "Laudatio Turlae" oxponuntur.

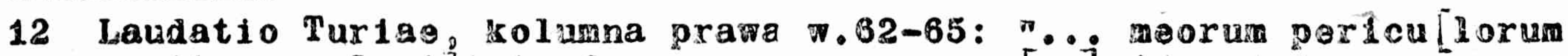
cogitans calam1] tate irangor nec permane[roj in promisao possum. Naturalis dolor extorquet const [an] t1ae rires: arore morsor ot quibu[s angor luctu taodioquo] in nocutro mint consto".

13 Factorum ot dietorum memorabilium 1 lber 71,2 /cap. Do Pido uxorum erga viros $\%$

14 Bella c1v111a IV 44.

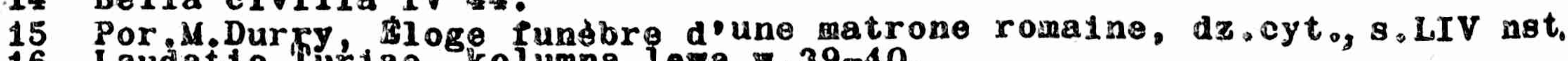

16 Laudatio Puriar, kolumna lowa v.39-40. 